\title{
Dynamics of Snail Populations of Biomphalaria glabrata and B. straminea under Semi-Natural Conditions
}

\section{Dinâmica das Populações dos Caramujos Biomphalaria glabrata e B. straminea em Condições Semi-Naturais}

\author{
Frederico S. Barbosa '; Odécio Sanches'; \\ Constança S. Barbosa ${ }^{2}$ \& Francisco Arruda ${ }^{2}$
}

\begin{abstract}
BARBOSA, F. S.; SANCHES, O.; BARBOSA, C. S. \& ARRUDA, F. Dynamics of Snail Populations of Biomphalaria glabrata and B. straminea under Semi-Natural Conditions. Cad. Sauide Públ., Rio de Janeiro, 8 (2): 157-167, abr/jun, 1992.

Growth curves and mortality rates for populations of Biomphalaria glabrata and B. straminea bred under semi-natural conditions are reported. Snail populations of the above species were maintained for 220 weeks in indoor cement channels. Data were recorded at 20 week intervals. Crude densities are significantly different for each of the studied populations. B. glabrata showed the lower figure while B. straminea $R 3$ strain showed the best performance. The latter is able to live in half the volume of water needed for $\mathrm{B}$. glabrata when both are submitted to population pressure.
\end{abstract}

Keywords: Snail Population Dynamics; Competitive Displacement; Biomphalaria; Brazil

\section{INTRODUCTION}

There is strong and diversified evidence showing that Biomphalaria straminea is an efficient competitor against $B$. glabrata (Barbosa, 1973; Michelson \& Dubois, 1979; Guyard \& Pointier, 1979; Barbosa et al., 1981, 1984, 1985; Barbosa, 1987). Studies on interactions between the two species demand a knowledge of the factors that may influence the competitive process. Among these factors growth and reproduction are the most relevant. In the current paper the population dynamics of B. straminea and $B$. glabrata living under semi-natural conditions, as previously described (Barbosa et al., 1983), is presented. This study is limited to the presentation and discussion of data on population growth, size-group distribution and mortality rates.

\footnotetext{
'Escola Nacional de Savide Pública. Rua Leopoldo Bulhoes, 1480, 21041-210, Rio de Janeiro, RJ, Brasil.

2 Centro de Pesquisas Aggeu Magalhäes, Campus da Universidade Federal de Pernambuco. Engenho de Meio, 50670-420, Recife, PE, Brasil.
}

\section{MATERIALS AND METHODS}

For the present observations, laboratory-reared strains of $B$. glabrata and $B$. straminea were used. The former (PA strain) originated from natural breeding places in the county of Paulista, about $40 \mathrm{Km}$ from Recife, in the coastal forest region of the State of Pernambuco, Brazil. Two strains of $B$. straminea were used: an albino black-eyed strain (PT) partially resistant to infection with Schistosoma mansoni, originated from irrigation ditches in the county of Petrolandia, $420 \mathrm{Km}$ west of the sea coast of the State of Pernambuco. The second one is a pure albino resistant strain, named $R 3$. This strain originated from Sete Lagoas, State of Minas Gerais, Brazil, was sent to Dr. C. S. Richards (Biomedical Research Institute, Rockville, Md, USA) by Dr. W. L. Paraense (Fundaçāo Oswaldo Cruz, Rio de Janeiro, Brazil). The albino R3 stock was obtained through exposure to infection and selection of the original Sete Lagoas strain (Richards, in letter to senior author, 1982). 
The snail populations were observed for the period of 220 weeks in separate indoors channels measuring $4.5 \mathrm{~m}$ long. Cement roof covers of the trade mark Kalheta built by Brasilit, were fixed upside down on strong supports in such a way that the upper end of the channel was held at $95 \mathrm{~cm}$ over the floor. Both ends of the channels were closed with cement walls. At one end of each channel a tap was fixed at $16 \mathrm{~cm}$ over the water surface. At the opposite end, an outlet was placed to regulate the volume of the water inside the channel. (Figure 1). Each channel holds 140.6 $(S D=1.9)$ average liters of water.

Both indoor aquaria and channels receive natural day light through ordinary windows. Artificial lights placed in the snail rooms to increase the amount of light was only used during cloudy dark days. Tap water was used in the channels during the experiments. The water before arriving to the channels is dechlorinated through consecutive passages in two tanks placed at the roof of the building. The water drops continuously over the surface of the water and its input is regulated in such a way that the whole content of the channel is replaced every thirty days. The water is kept at $\mathrm{pH}$ neutral point by using calcium carbonate powder. Sand is screened and washed in the laboratory before its use. The water temperature is kept at $22.4 \mathrm{C}$ $(\mathrm{SD}=1.77$ ) by the use of air conditioning ordinary equipment which is only used in hot days during summer. Lettuce was the everyday food for the snails. In addition, on alternate weeks, the snails were offered cooked-leaves of stinging-nettle (Fleurya aestuans), fresh wheat germ and fish-food power. Elodea sp. was the only species of aquatic plant introduced in the channels. Each colony was started by seeding with 250 mature snails. The snail population dynamics were studied by examination of a 20 per cent sample taken at intervals of 20 weeks. For each channel, three fixed collecting stations were established at regular intervals along the channels. Each station was made of a cross segment of a channel of the same size, and inserted as a lining sheet over the inner surface of the channels used in the experiments. The content of the three stations corresponds to 20 per cent of the whole volume of the channel water. At the moment of the sampling colection, both open sides of the stations are

FIGURE 1 - Longitudinal and Cross Section Views of a 4.5mm Long Channel (From Barbosa et al., 1983)

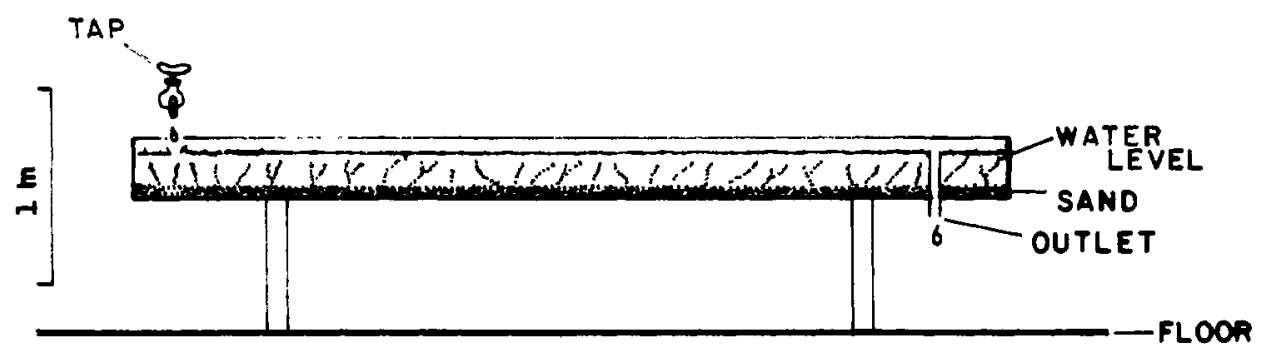

LONGITUDINAL SECTION

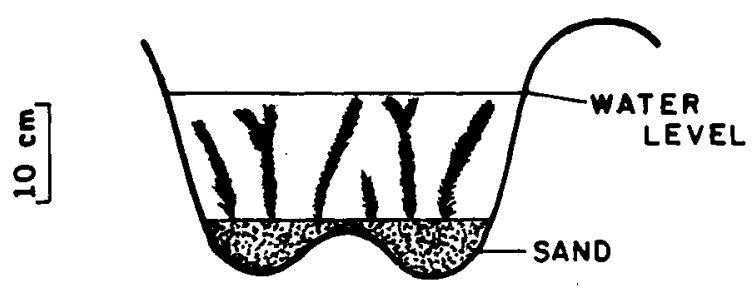

CROSS SECTION 
tightly closed with wooden walls kept in place by means of two clamps each. To avoid escaping of very young snail specimens the wooden pieces are set in a frame of soft rubber. At that moment, the whole channel segment (collecting station) is gently pulled up while the water content leaks through screened holes placed at the lateral surfaces of the wooden pieces. The whole content of the sample is then spread over a large shallow pan and the snails are counted and measured. Plants and sand are carefully examined under a low magnification stereoscope. After this operation, snails are put back in the channels.

In the experimental channels, it was observed that a variable number of snails gathered around air bubbles formed on the surface of the water resulting from the dropping of water from the feeding faucets. To avoid this inconvenience the faucets were closed $48 \mathrm{~h}$ before the counting time. A similar phenomenon occurred with pieces of lettuce around which groups of snails used to gather. For this reason snails were not fed during $48 \mathrm{~h}$ before sampling (Barbosa et al., 1983).

Snails were classified in four size (maximum diameter) groups as follow: $B$. glabrata $\geq 6.9$, $7.0-11.9,12.0-16.9$, and $\geq 17.0 \mathrm{~mm} ; B$. straminea $\leq 3.9,4.0-5.9,6.0-7.9$, and $\geq 8.0$ $\mathrm{mm}$. The relationship between age and size is very complex and variable. Although age cannot be determined precisely it was decided to divide snail populations in size-groups, for theoretical reasons and according to our own experience. The results obtained in the current studies seem to warrant this decision.

The statistical analysis was carried out on the following points: (1) stability of the survival proportions in the snail populations through the proportions trend test (Armitage, 1974); (2) estimation of the stability straight lines for the number of survivors; (3) hypothesis tests for the straight line $b$ coefficients; (4) estimation of the common $b$ coefficient to the stability straight line; and (5) covariance analysis for the straight line interceptions. The statistical analysis was carried out on the whole snail population samples, independent of their divisions into size-groups.

\section{RESULTS}

Descriptive results are shown in Tables 1 to 3 and Figures 2 to 5. Data from statistical analysis are presented in the text and in Figures 2 to 4 . Tables 1 to 3 show the absolute numbers of snails per sample: mortality is shown in absolute numbers and percentages (in brackets).

In Figures 2 to 4, data on the absolute growth rates of the snail populations are plotted. At the bottom of these figures the percentage distribution of specimens according to size-groups, are seen.

The values of $\chi^{2}$ in the proportions trend test (data from Tables 1 to 3 ) for the survival of the snail populations, indicate that the growth curves of the three studied populations follow similar patterns:

a) Biomphalaria glabrata population tends to become stable beginning the 60th week $\left(\chi_{7}^{2}\right.$ of $=9.39 ; 0.20<P<0.30$ ). Adjustment of the straight line for the stability period is represented by the equation $\mathrm{y}=150.1+0.31 \mathrm{x}$ (observation corresponding to 100 th week was considered atypical);

b) for $B$. straminea, PT strain, the period of stability was attained at the 120 th observation week $\left(\chi_{4 \text { of }}^{2}=5.04 ; 0.20<P<0.30\right.$. The stability straight line equation was estimated as $y=224.5-0.10 x$ (mortality rate at 160 th week point was considered atypical);

c) the stability period of $B$. straminea, R3 strain, begins at 160 th week $\left(\chi_{2 \mathrm{df}}^{2}=0.51 ; 0.70\right.$ $<\mathrm{P}<0.80$ ) and the estimated stability line corresponds to the equation $y=309.3+0.145 x$.

The hypothesis test for the $b$ coefficient of the three stability straight lines shows that the null hypothesis is not disproved in any of the snail populations studied $\mathrm{t}_{7 \text { df }}=0.34 ; 0.70<\mathrm{P}$ $<0.80$ for $B$. glabrata; $\mathrm{t}_{4 \text { df }}=0.71 ; 0.50<\mathrm{P}<$ 0.60 for $B$. straminea PT strain; and $t_{2 d t}=$ 


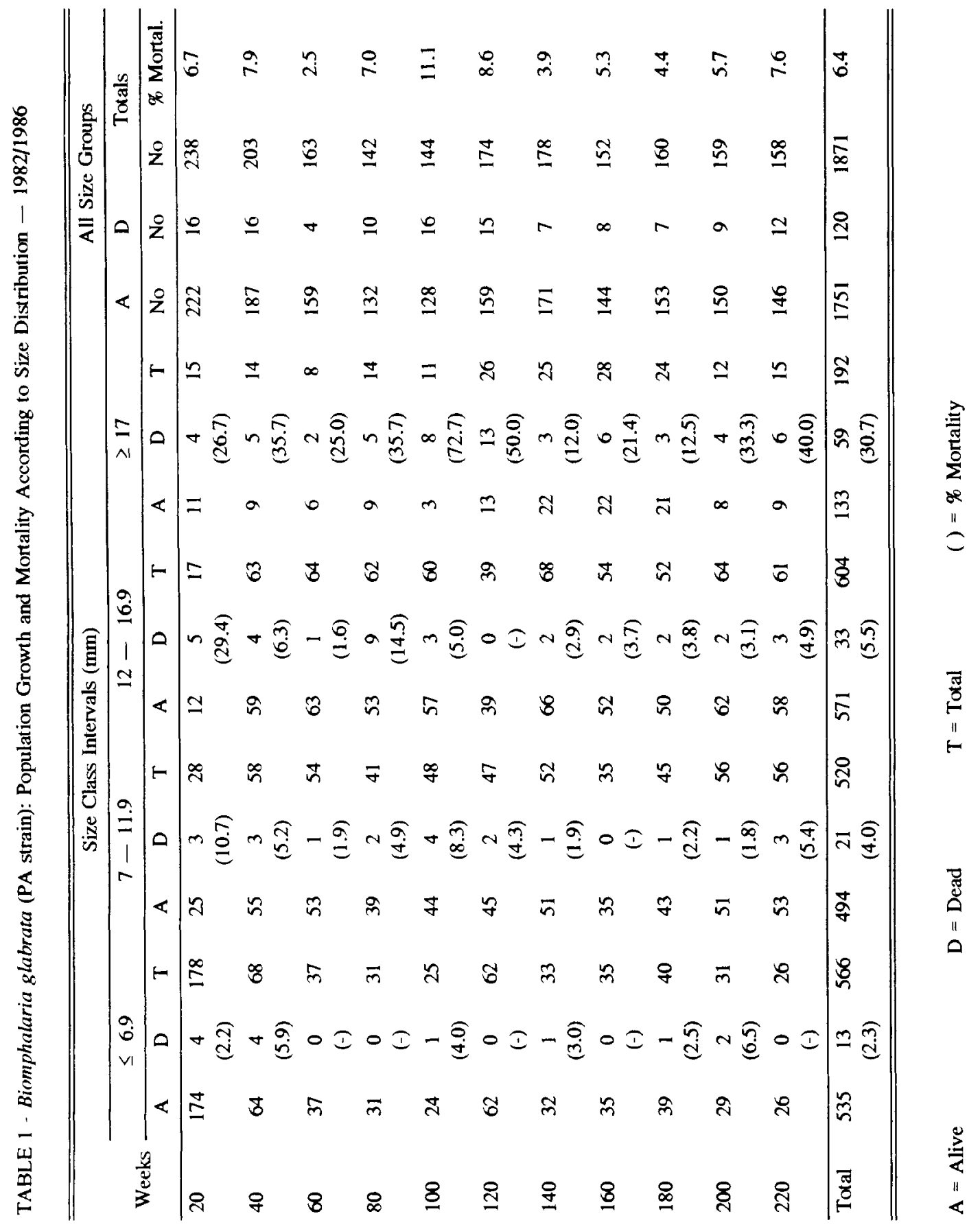




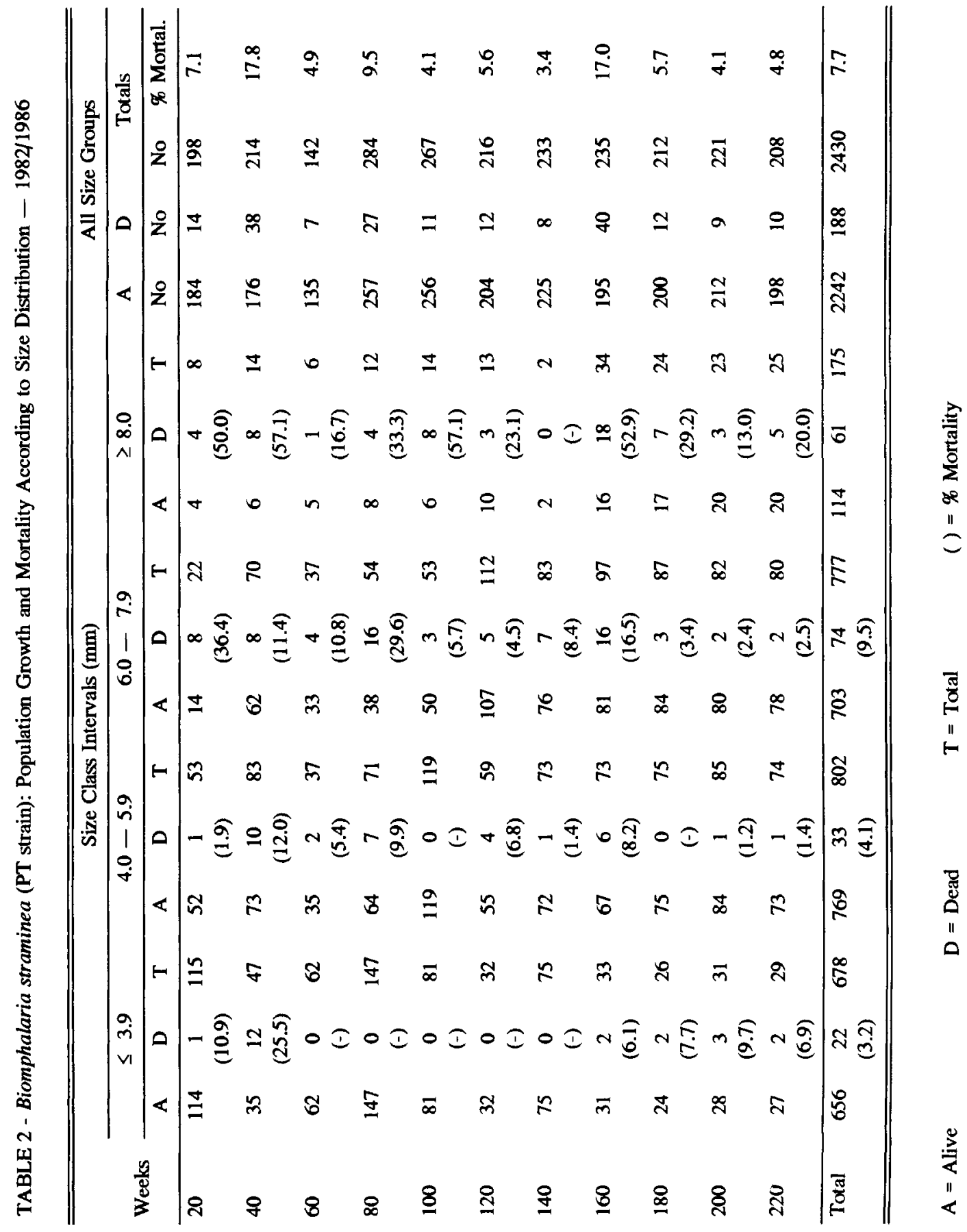




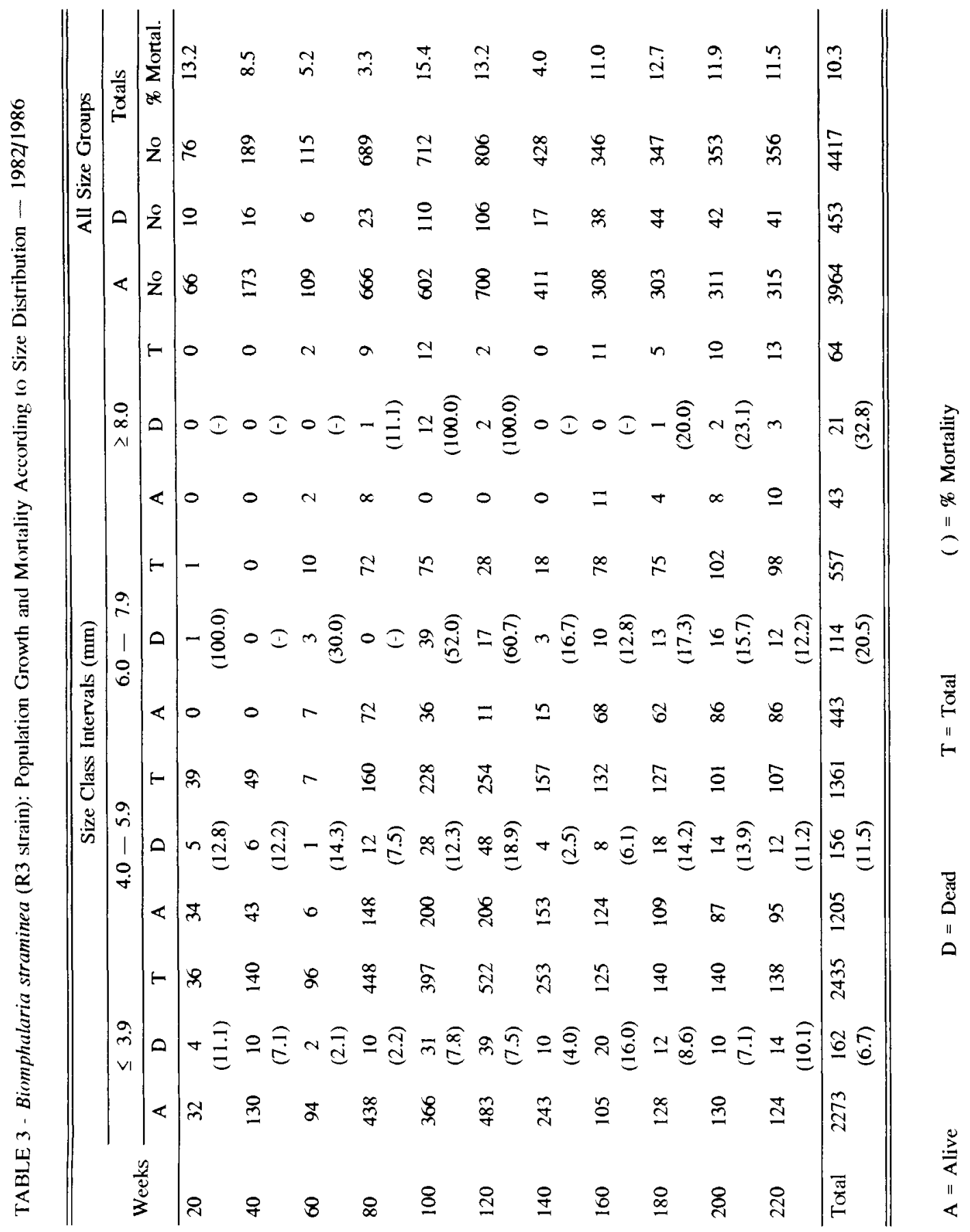


1.56; $0.20<\mathrm{P}<0.30$ for $\mathrm{B}$. straminea $\mathrm{R} 3$ strain). The common $b$ coefficient for the three stability straight lines was estimated as $b_{c}=0.0094$. So, the equations for the adjusted stability straight line with $b_{c}=$ 0.0094 , were as follows: B. glabrata $\mathrm{y}=$
$105.1+0.0094 \mathrm{x} ;$ and $B$. straminea, PT strain, $y=205.4+0.0094 x ;$ and $B$. straminea, R3 strain, $y=307.2+0.0094 x$ (Figures 2 to 4).

Covariance analysis shows that the straight line intercepts differ significantly.

FIGURE 2 - Biomphalaria glabrata (PA strain): Population Growth and Size Distribution - 1982/1986

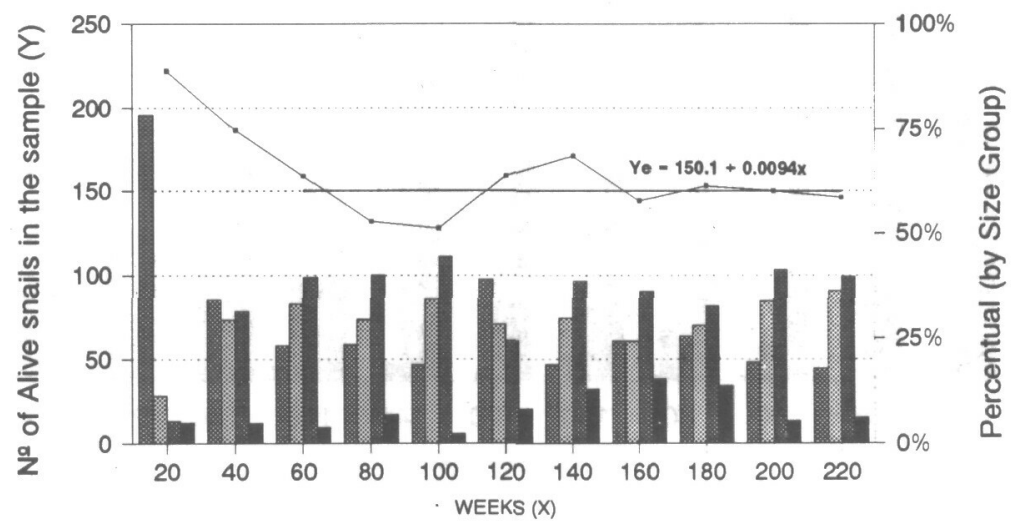

Size Groups

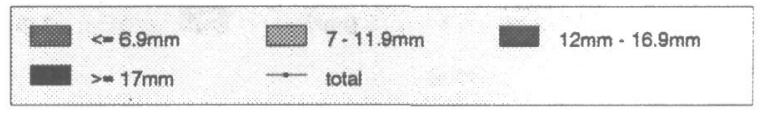

FIGURE 3 - Biomphalaria straminea (PT strain): Population Growth and Size Distribution - 1982/1986

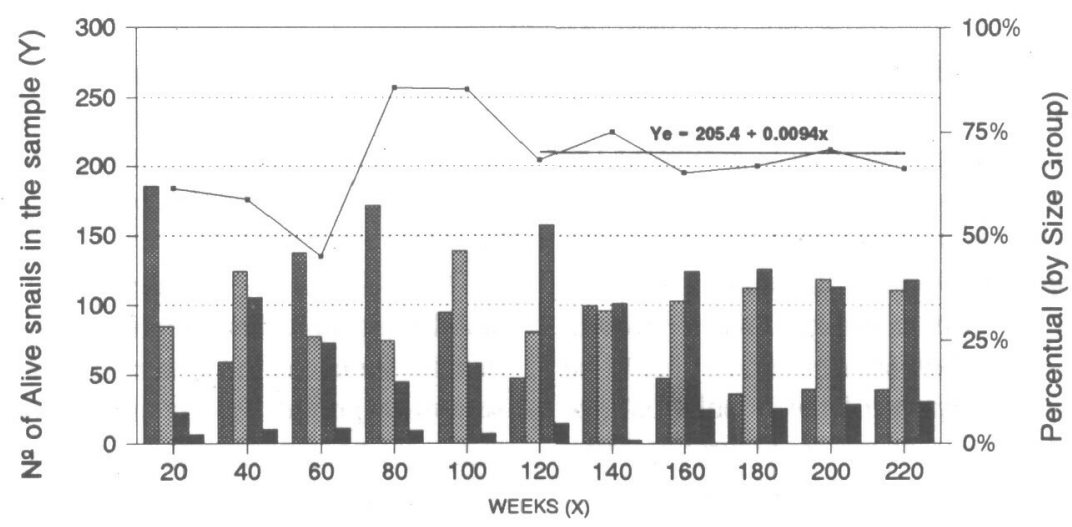

Size Groups

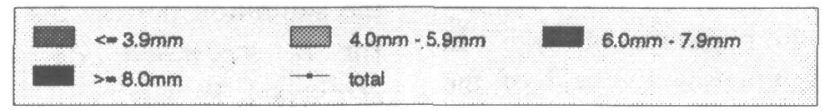


FIGURE 4 - Biomphalaria straminea (R3 strain): Population Growth and Size Distribution - 1982/1986

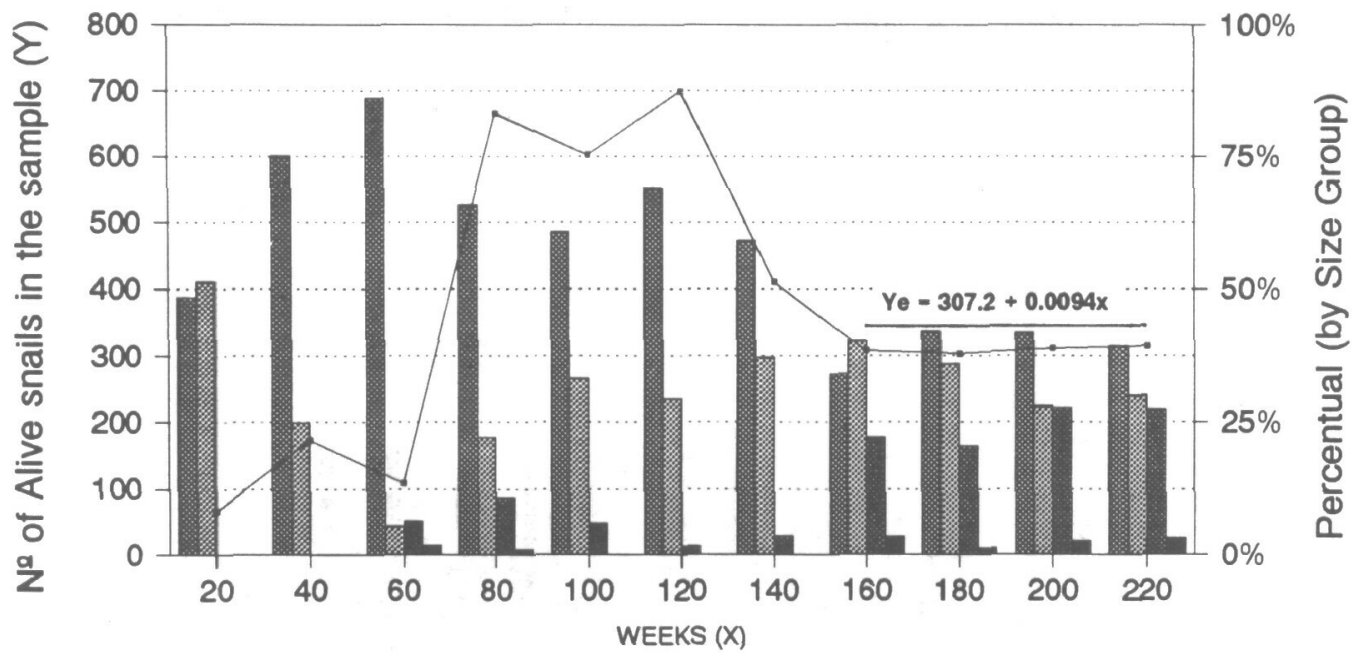

Size Groups

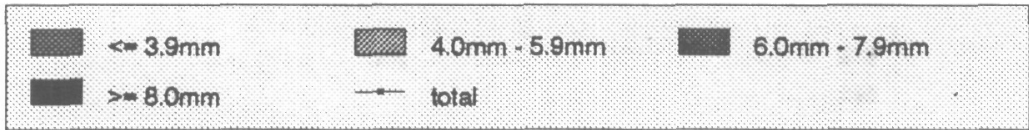

Figure 5 shows the comparative percentage mortality rates for each of the Biomphalaria strains studied, according to size-groups at the end of 220th week observation period.

The data analysis shows that the saturation (carrying capacity) level of the snail colonies is attained at the last countings when growth begins to oscillate between limits that could be considered as variations of the population size at a constant volume of water. Saturation level can be also ascertained by changes which occurred in the size-group distributions. As seen in the growth curves (Figures 2 to 4 ), the size-group distributions tend to show a regular balance among the four groups of "age" in which were divided, towards the end of the experiment.
There is marked variation among the species/strains of Biomphalaria, as expected. These variations are related to the number of snails as well as to the period in which they occur.

The values of $y$ calculated through the stability straight lines represent the snail crude density for each species/strain population of the saturation period. Taking into account the whole volume of water per channel $(\bar{x}=140.6, \mathrm{SD}$ $=1.9$, liters) and the number of snails estimated as the crude density, it was possible to estimate the number of snails per liter of water during the saturation period: $\mathbf{5 . 5}$ for $B$. glabrata; 7.3 for $B$. straminea, PT strain; 10.9 for $B$. straminea, $\mathbf{R} 3$ strain. 
FIGURE 5 - Mortality Rates According to Size Groups for the Total Observation Period - 1982/1986
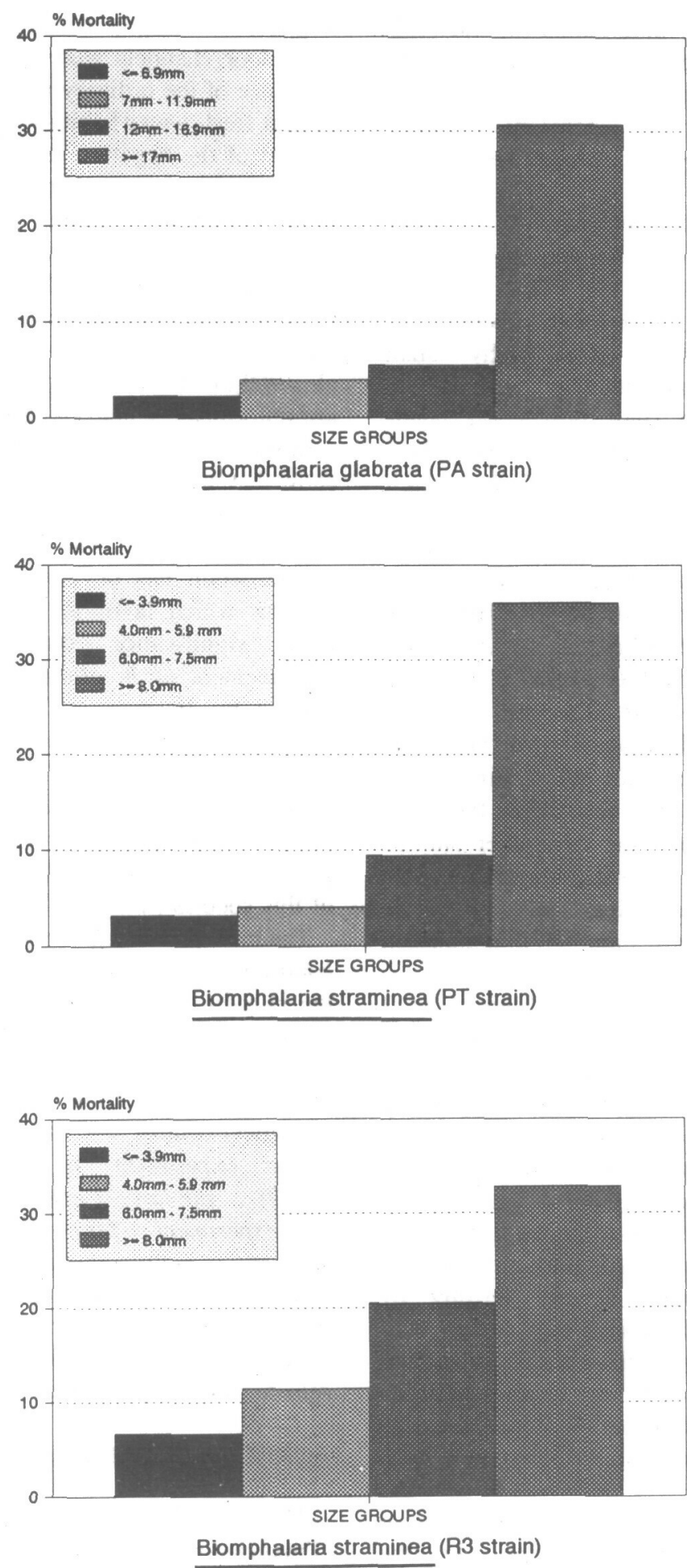


\section{DISCUSSION}

Results show that populations of Biomphalaria can be maintained satisfactorily under semi-natural conditions for at least 220 weeks, and probably for much longer periods. We still have in our laboratory channels flourishing colonies of $B$. glabrata kept for six years.

This method opens perspectives for other types of studies such as snail ecology, genetics and related subjects.

We did not find any reliable procedure to calculate the biomass for eachy snail population. However, it was possible to estimate the higher snail population levels (crude density) in the channels at the periods in which the populations attained their greatest densities (saturation). These figures are significantly different for each of the studied populations. The lower figure for $B$. glabrata can be explained, in part, by the larger size attained by those individuals. $B$. straminea R3 strain population took 160 weeks. $B$. glabrata attained the same level at 60 weeks.

On the other hand, it was shown that under population pressure, the R3 strain of $B$. straminea attains higher density in the same volume of water than the two other studied snail populations. As a result, this strain is able to live in half the volume needed by $B$. glabrata when both are submited to population pressure.

Mortality data presented in Tables 1 to 3 should be taken with caution. As snail countings were made at $\mathbf{2 0}$ week intervals, it is understandable that some snail shells, specially the juvenile ones, may disintegrate during the 140 day period between each sampling.

It was not possible to complete data on snail demography due to some technical difficulties. For instance, we did not find any reliable technique to estimate directly fertility by counting the number of snail eggs laid.

It is usually accepted that a stable population is kept in equilibrium by the balance between the limits to population growth imposed by the environment and the potential inherent growth of the population.

Particular situations were created in the so called "semi-natural" conditions. In the particular case of the current study, the snail population cycles were independent of the cyclic fluctuations due to external environmental factors. Another factor to be mentioned is that the Biomphalaria snails bred in in-door channels were not submited to the influence of the ordinary macro-fauna found in natural fresh-water habitats.

Most of the negative intraspecific effects on population growth reported in the literature were observed in snail kept in "closed" laboratory systems. As the experimental snails are generally maintained in laboratory glass aquaria under variable conditions this makes quantitative comparison difficult (Hairston et al., 1960). Comparisons with the present system are unfortunately not possible.

Results obtained in the current paper clearly show that different behavioral patterns emerged from the studied populations of Biomphalaria (Figures 2 to 4). This indicates that each species/strain has developed inherent growth patterns which favor $B$. straminea. This may have significance on the competitive displacement of $B$. glabrata by $B$. straminea studied by Barbosa $(1973,1987)$ and other Authors (Guyard \& Pointier, 1979: Michelson \& Dubois, 1979).

The presence of $B$. straminea in Hong Kong and its spreading to new regions of south China give a very good idea of the adaptative capacity of this species (Yipp, 1990).

The most promising method for the biological control of the snail vectors of schistosomiasis is the introduction of competitor non-susceptible snails (WHO, 1987). Madsen (1990), complemented by Coimbra (1991) covered most of the recent literature dealing with snail biological control.

The experiment by Barbosa-Figueiredo (1989), ... the largest controlled and long-term field experiment so far conducted on congeneric competition in Biomphalaria... (Coimbra, 1991) shows that ... biological control based on competitive displacement between close species holds important potential in the control of schistosomiasis (Coimbra, 1991).

\section{ACKNOWLEDGMENTS}

This work was supported by the "Financiadora de Projetos e Pesquisa", Finep, the "Superintendência de Desenvolvimento do 
Nordeste", Sudene, the "Conselho Nacional de Desenvolvimento Científico e Tecnológico", $\mathrm{CNPq}$, and the Agency for International Development, USA.

\section{RESUMO}

BARBOSA, F. S.: SANCHES, O.; BARBOSA, C. S. \& ARRUDA, F. Dinâmica das Populaçōes dos Caramujos Biomphalaria glabrata e B. straminea em Condições Semi-Naturais. Cad. Saúde Públ., Rio de Janeiro, 8 (2): 157-167, abr/jun, 1992.

Curvas de crescimento e taxas de mortalidade para populações de Biomphalaria glabrata e $B$. straminea, criadas em condiçōes semi-naturais, são descritas no presente trabalho. As populaçōes dos caramujos foram observadas durante 220 semanas em canaletas de cimento montadas no laboratório. Dados foram coletados a cada intervalo de 20 semanas. As densidades brutas de crescimento foram significantemente diferentes para cada população estudada. $B$. glabrata mostrou crescimento inferior às duas cepas de $B$. straminea. A cepa R3 desta última espécie mostrou o melhor desempenho, sendo capaz de viver em metade do volume de água necessária a $B$. glabrata quando ambas estão submetidas a pressão populacional.

Palavras-Chave: Dinâmica de Populações de Caramujos; Deslocamento Competitivo; Biomphalaria; Brasil

\section{REFERENCES}

ARMITAGE, P., 1974. Statistical Methods in Medical Research. Blackwell Scientific Publications, $3^{\text {rd }}$ edition. Oxford: Great Britain.

BARBOSA-FIGUEIREDO, C., 1989. Interaçōes entre espécies de Biomphalaria, moluscos transmissores da esquistossomose no nordeste do Brasil. MSC Thesis, João Pessoa: Universidade Federal da Paraiba.

BARBOSA, F. S., 1973. Passible competitive displacement and evidence of hybridization, between two Brazilian species of planorbid snails. Malacologia, 14: 401-408.
1987. Competitive displacement of Biomphalaria glabrata by $B$. straminea. Memórias do Instituto Oswaldo Cruz, 82: 139-141.

BARBOSA, F. S.; PEREIRA DA COSTA, D. P. \& ARRUDA, F., 1981. New field observations on the competitive displacement between two species of planorbid snail inhabiting north eastern Brazil. Memórias do Instituto Oswaldo Cruz, 78: 361-366.

, 1983. Competitive interactions between species of freshwater snails. I. Laboratory, Ia. General methodology. Memórias do Instituto Oswaldo Cruz, 78: 335-341.

1984. Competitive interactions between species of freshwater snails I. Laboratory studies, Ib. Comparative studies of the dispersal and the vagility capabilities of Biomphalaria glabrata and B. straminea. Memórias do Instituto Oswaldo Cruz, 79: 163-167.

1985. Competitive interactions between species of freshwater snails. I Laboratory studies. Ic. Comparative survival of Biomphalaria glabrata and B. straminea kept out of water. Memórias do Instituto Oswaldo Cruz, 80: 155157.

COIMBRA Jr., C. E. A., 1991. Biological Control for Fresh water snails. Letters to the Editor. Parasitology Today, 7: 124.

GUYARD, A. \& POINTIER, J. P., 1979. Faune malacologique dulciaquicole et vecteurs de la schistosomose intestinale en Martinique. Annales de Parasitologie, 54: 193-205.

HAIRSTON, N. G., SMITH, F. E., \& SLOBODKIN, L. B., 1960. Community structure, population control and competition. The American Naturalist, 94: 421-425.

MADSEN, H., 1990. Biological Methods for the Control of Freshwater Snails. Parasitology Today, 6: 237-241.

MICHELSON, E. H. \& DUBOIS, L., 1979. Competitive interaction between two snail hosts of Schistosoma mansoni: laboratory studies of Biomphalaria glabrata and B. straminea. Revista do Instituto de Medicina Tropical de São Paulo, 21: 246-253.

WORLD HEALTH ORGANIZATION, 1987. Report on a informal consultation on the detection, isolation, identification and ecology of biological agents of disease vectors. TDR/BCV/IC-GE/87.3.

YIPP, M. W., 1990. Distribution of the schistosomose vector snail Biomphalaria straminea (Pulmonata, Planorbidae) in Hong Kong. The Journal of Molluscan Studies, 56: 47-55. 